\title{
Reclassification of Leuconostoc argentinum as a later synonym of Leuconostoc lactis
}

\author{
Correspondence \\ Marc Vancanneyt \\ Marc.Vancanneyt@UGent.be
}

\author{
Marc Vancanneyt, ${ }^{1}$ Medana Zamfir, ${ }^{2}$ Marjan De Wachter, ${ }^{1}$ \\ Ilse Cleenwerck, ${ }^{1}$ Bart Hoste, ${ }^{1}$ Franca Rossi, ${ }^{3}$ Franco Dellaglio, ${ }^{3}$ \\ Luc De Vuyst ${ }^{4}$ and Jean Swings ${ }^{1}$ \\ ${ }^{1}$ BCCM/LMG Bacteria Collection, Laboratory of Microbiology, Faculty of Sciences, Ghent \\ University, Ledeganckstraat 35, B-9000 Ghent, Belgium \\ ${ }^{2}$ Institute of Biology, Romanian Academy, Cell Biology Department, Splaiul Independentei 296, \\ 060031 Bucharest, Romania \\ ${ }^{3}$ Dipartimento Scientifico e Tecnologico, Università degli Studi di Verona, Strada le Grazie 15, \\ I-37134 Verona, Italy \\ ${ }^{4}$ Research Group of Industrial Microbiology, Fermentation Technology and Downstream \\ Processing (IMDO), Department of Applied Biological Sciences and Engineering, Vrije \\ Universiteit Brussel (VUB), Pleinlaan 2, B-1050 Brussels, Belgium
}

Leuconostoc argentinum was described as a separate species, distinct from Leuconostoc lactis, based on total soluble cell protein analysis, DNA-DNA hybridization experiments and phenotypic data (Dicks et al., 1993). No 16S rRNA gene sequence data were available at that time. In a recent study on the biodiversity of lactic acid bacteria from traditional Romanian dairy products, a number of strains could not be assigned to either L. argentinum or L. lactis after numerical analysis of repetitive extragenic palindromic-PCR (REP-PCR) patterns (unpublished results). $16 \mathrm{~S}$ rRNA gene sequence data (available at EMBL) for members of the genus Leuconostoc show that $L$. argentinum and $L$. lactis are nearest neighbours ( $>99.6 \%$ sequence similarity) and constitute a separate

Published online ahead of print on 16 September 2005 as DOI 10.1099/ijs.0.63898-0.

Abbreviations: FAFLP, fluorescent amplified fragment length polymorphism; REP-PCR, repetitive extragenic palindromic-PCR.

The GenBank/EMBL/DDBJ accession numbers for the 16S rRNA gene sequences of Leuconostoc lactis LMG 22650 and R-21065 are AJ970316 and AJ937759, respectively.

A dendrogram based on (GTG) 5 -PCR fingerprints and a table detailing the phenotypic features of Leuconostoc lactis strains are available as supplementary material in IJSEM Online. phylogenetic branch together with a third species, Leuconostoc citreum. A polyphasic study was performed to investigate the taxonomic relatedness between $L$. argentinum and L. lactis strains and the Romanian dairy isolates.

Strains studied included (i) two reference strains of L. lactis, LMG $8894^{\mathrm{T}}$ and LMG 7940, isolated from milk and cheese, respectively; (ii) the type strain of $L$. argentinum LMG $18543^{\mathrm{T}}$, from Argentinian raw milk; and (iii) ten Romanian isolates: strains LMG 22631, LMG 22635 and R-19870 from raw cows' milk, strains LMG 22614, LMG 22627, LMG 22628 and LMG 22660 from sour cream and strains LMG 22591, LMG 22650 and R-21065 from cheese. All strains used in this study were obtained from the BCCM/LMG Bacteria Collection (http://www.belspo.be/bccm/lmg.htm) and were cultivated and maintained on de Man, Rogosa and Sharpe (MRS) agar medium (de Man et al., 1960) and were incubated aerobically at $30^{\circ} \mathrm{C}$, unless otherwise indicated.

REP-PCR fingerprinting with the $(G T G)_{5}$ primer was initially applied as a deduplication approach for all Romanian lactic acid bacteria isolates collected from dairy products (unpublished results). Subsequent analysis of the patterns was performed using the BioNumerics software version 4.0 according to Gevers et al. (2001). The $(\mathrm{GTG})_{5}-\mathrm{PCR}$ 
fingerprints obtained were compared with an in-house database covering reference strains of all Leuconostoc species. L. lactis, L. argentinum and the ten Romanian strains displayed similar fingerprints. Cluster analysis grouped them into a single cluster, clearly separated from fingerprints obtained for the other Leuconostoc species (data not shown). (GTG) $)_{5}$-PCR fingerprint patterns obtained from the strains investigated in this study and revealing their differentiation from the phylogenetically closest species, Leuconostoc citreum, are available in Supplementary Fig. S1 in IJSEM Online.

All strains of the L. argentinum-L. lactis cluster were further screened using SDS-PAGE of whole-cell proteins. Wholecell protein extracts were prepared and SDS-PAGE was performed as described by Pot et al. (1994). Densitometric analysis, normalization and interpolation of protein profiles and a numerical analysis were performed by using GELCOMPAR software, versions 3.1 and 4.0, respectively (Applied Maths). A dendrogram confirmed that the L. lactis, L. argentinum and Romanian isolates constitute a homogeneous and separate cluster that is distinct from $L$. citreum (Fig. 1) and other Leuconostoc species (data not shown).

Because of its higher taxonomic resolution compared with SDS-PAGE of proteins (Gancheva et al., 1999; Torriani et al., 2001), all reference strains and novel isolates were also investigated using fluorescent amplified fragment length polymorphism (FAFLP) fingerprinting of whole genomes. FAFLP fingerprinting was performed as described by Thompson et al. (2001) with the following modifications: EcoRI/TaqI was used as the restriction enzyme combination and the primer combination E01/T01 (both having an adenosine extension at the 3 -end) was applied for selective PCR. The resulting electrophoretic patterns were tracked and normalized using the GENESCAN 3.1 software (Applera). Normalized tables of peaks, containing fragments of 50 $536 \mathrm{bp}$, were transferred into the BioNumerics software package, version 3.5, and the computer-generated fingerprints were added to an existing database of FAFLP fingerprints of lactic acid bacteria at the BCCM/LMG Bacteria Collection. For numerical analysis, data between the 75 and
$500 \mathrm{bp}$ bands of the internal standard were used. Similarity was calculated using the Dice coefficient and clustering was done using the UPGMA algorithm. The FAFLP fingerprints of all strains were compared with reference profiles of lactic acid bacteria taxa as currently available in the database. FAFLP analysis revealed a high similarity between L. lactis, L. argentinum and the Romanian isolates. Fig. 2 shows a dendrogram in which the latter strains grouped in a single cluster separated from the related reference species L. citreum.

The phylogenetic position of the Romanian isolates R-21065 and LMG 22650 was determined by complete $16 \mathrm{~S}$ rRNA gene sequence analysis performed as described by Vancanneyt et al. (2004) with the following modifications. PCR-amplified 16S rRNA genes were purified by using a NucleoFast 96 PCR clean-up kit (Macherey-Nagel). Sequencing reactions were purified using a Montage SEQ $_{96}$ sequencing reaction cleanup kit (Millipore). Sample preparation was assisted using a Genesis Workstation 200 (Tecan). Electrophoresis of sequence reaction products was performed by using an $\mathrm{ABI}$ Prism 3100 Genetic Analyzer (Applied Biosystems). The 16S rRNA gene sequences (continuous stretches of $1502 \mathrm{bp}$ ) and sequences of strains retrieved from EMBL were aligned and a comparison of the newly determined complete sequences revealed a sequence similarity of $99 \cdot 8 \%$. A comparison with sequences available in the EMBL database classified the strains with nearest neighbours $L$. lactis and L. argentinum (sequence similarities above $99 \cdot 8$ and $99 \cdot 6 \%$, respectively). Within the genus Leuconostoc, these taxa and L. citreum occupy a distinct branch.

DNA G $+C$ contents were determined for $L$. argentinum LMG $18543^{\mathrm{T}}$, L. lactis LMG $8894^{\mathrm{T}}$ and LMG 7940, L. citreum LMG $9849^{\mathrm{T}}$ and strains LMG 22627, LMG 22628, LMG 22635 and R-21065. DNA was extracted from $0 \cdot 75-1 \cdot 25 \mathrm{~g}$ (wet weight) of cells according to the protocol described by Gevers et al. (2001) using a combination of glass beads and enzymes, but with the following modifications. Volumes were increased ten-fold for application on a large scale. Vortexing with beads of the SDS-treated cells was performed for $30 \mathrm{~s}$. After addition of $16.5 \mathrm{ml}$ buffer $(10 \mathrm{mM}$ Tris/ $\mathrm{HCl}$,

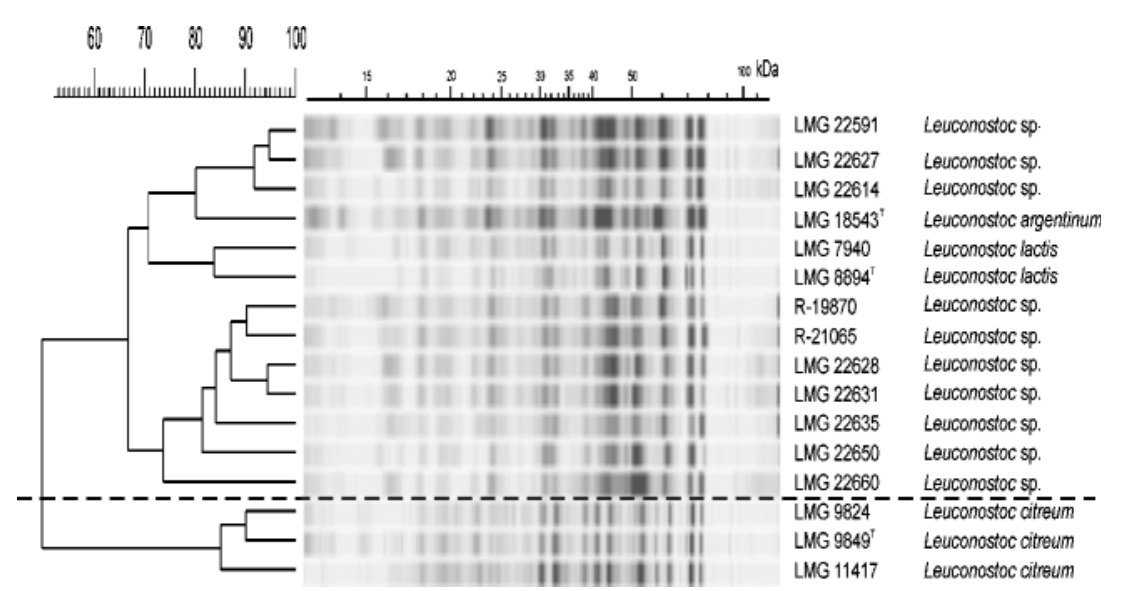

Fig. 1. Protein profiles and corresponding dendrogram, derived from UPGMA linkage of correlation coefficients ( $r$, expressed as a percentage value for convenience) of $L$. argentinum, L. lactis, L. citreum and related strains from Romanian dairy products. 


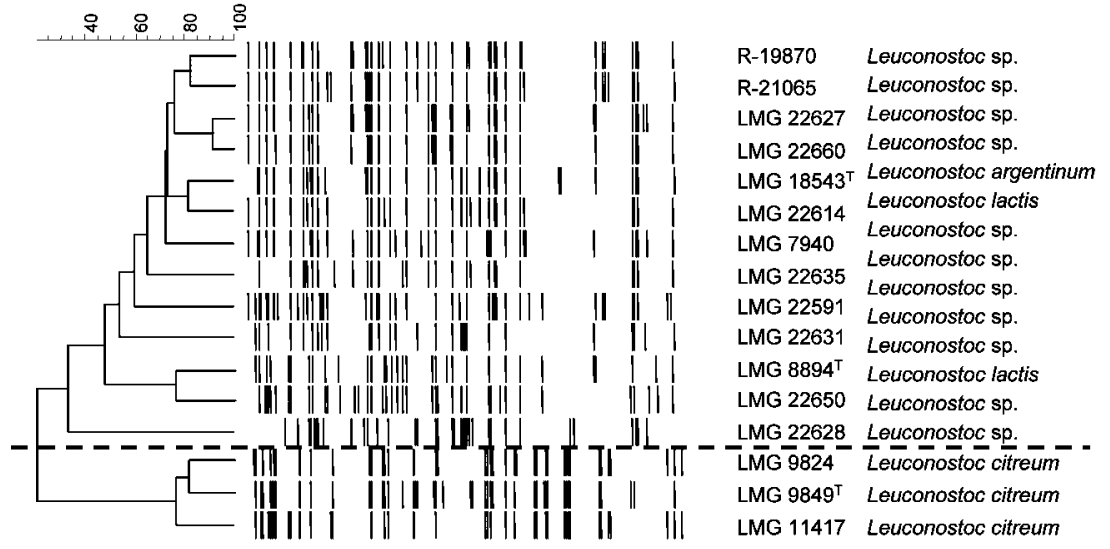

Fig. 2. FAFLP patterns and corresponding dendrogram, derived from the UPGMA linkage of Dice coefficients (expressed as a percentage value for convenience) of $L$. argentinum, $L$. lactis, $L$. citreum and related strains isolated from Romanian dairy products.
$100 \mathrm{mM}$ EDTA, $\mathrm{pH} \mathrm{8.0)}$ and $5 \mathrm{ml} 5 \mathrm{M} \mathrm{NaCl}$ and gentle shaking, the suspension was incubated at $65^{\circ} \mathrm{C}$ for $10 \mathrm{~min}$. Subsequent chloroform/isoamylalcohol extraction, precipitation, spooling of DNA on a glass rod, washing with ethanol and RNase treatment was performed as described by Marmur (1961). After the RNase treatment, proteinase K ( $1 \mathrm{mg} \mathrm{ml}^{-1}$; VWR International) was added to the mixture. For determination of the DNA G $+C$ content, DNA was enzymically degraded into nucleosides as described by Mesbah et al. (1989). The nucleoside mixture was then separated by HPLC using a Waters SymmetryShield C8 column maintained at $37^{\circ} \mathrm{C}$. The solvent was $0.02 \mathrm{M}$ $\left(\mathrm{NH}_{4}\right) \mathrm{H}_{2} \mathrm{PO}_{4}(\mathrm{pH} 4 \cdot 0)$ with $1.5 \%$ acetonitrile. Nonmethylated lambda phage DNA (Sigma) was used as the calibration reference. DNA G $+\mathrm{C}$ contents of L. argentinum and L. lactis were 42 and $43 \mathrm{~mol} \%$, respectively. These values were close to the value of $40 \cdot 5 \mathrm{~mol} \%$ which was determined for the type strain of L. argentinum (Dicks et al., 1993) and also in the range of $43-45 \mathrm{~mol} \%$ determined for L. lactis (Garvie, 1986). Similar values of $42 \mathrm{~mol} \%$ were obtained for all the Romanian isolates. For the type strain of L. citreum, the value of $39 \mathrm{~mol} \%$ determined in this study was similar to the value of $38-40 \mathrm{~mol} \%$ described in the literature (Farrow et al., 1989).

DNA-DNA hybridizations were performed between $L$. argentinum LMG $18543^{\mathrm{T}}$, L. lactis LMG $8894^{\mathrm{T}}$ and LMG 7940, L. citreum LMG $9849^{\mathrm{T}}$ and strains LMG 22627, LMG 22628, LMG 22635 and R-21065. DNA was prepared as described above. The microplate method was used as described by Ezaki et al. (1989) and Goris et al. (1998), using an HTS7000 Bio Assay Reader (Perkin Elmer) for fluorescence measurements. Biotinylated single-stranded DNA (ssDNA) was hybridized with unlabelled ssDNA, which was bound non-covalently to microplate wells. Hybridizations were performed at $37^{\circ} \mathrm{C}$ in a hybridization mixture containing $2 \times$ SSC, $5 \times$ Denhardt's solution, $2 \cdot 5 \%$ dextran sulfate, $50 \%$ formamide, $100 \mu \mathrm{g}$ denatured salmon sperm DNA $\mathrm{ml}^{-1}$ and $1 \cdot 25 \mu \mathrm{g}$ biotinylated probe DNA $\mathrm{ml}^{-1}$. The DNADNA hybridization value between the type strain of $L$. argentinum and the type strain of L. lactis was $81 \%$, indicating that they constitute a single species. The value determined in this study was significantly higher than that given in Dicks et al. (1993). Four Romanian isolates, LMG 22627, LMG 22628, LMG 22635 and R-21065 could be assigned to this single species with values ranging from 72 to $94 \%$. L. citreum was clearly distinct, with DNA-DNA relatedness values below $23 \%$ with all strains tested.

Biochemical features were investigated by both conventional fermentation tests and the standard commercial identification system API $50 \mathrm{CH}$ (bioMérieux). The inoculum size was $1 \%(\mathrm{v} / \mathrm{v})$ and was prepared by growing a single colony of each strain for $24 \mathrm{~h}$, centrifuging $1 \mathrm{ml}$ culture at 8000 r.p.m. for $2 \mathrm{~min}$ and resuspending the cells in $1 \mathrm{ml}$ sterile physiological solution $(0.9 \% \mathrm{NaCl} w / \mathrm{v})$. The culture assay medium, prepared in the laboratory or provided by the manufacturer (for the conventional and API tests, respectively), had the following composition $\left(1^{-1}\right)$ : $10 \mathrm{~g}$ polypeptone, $5 \mathrm{~g}$ yeast extract, $2 \mathrm{~g}$ dipotassium phosphate, $5 \mathrm{~g}$ sodium acetate, $2 \mathrm{~g}$ diammonium citrate, $0 \cdot 2 \mathrm{~g}$ magnesium sulfate, $0 \cdot 05 \mathrm{~g}$ manganese sulfate, $1 \mathrm{ml}$ Tween 80 , $\mathrm{pH} 6 \cdot 7-$ $7 \cdot 1$. For the conventional biochemical tests, carbohydrates (sucrose, D-lactose, D-fructose, L-arabinose, D-xylose, Dmaltose, D-trehalose, D-galactose and salicin) were added to a final concentration of $5 \mathrm{~g} \mathrm{l}^{-1}$. Cultures were incubated at $37^{\circ} \mathrm{C}$ for $48 \mathrm{~h}$. Results of conventional and API tests were congruent and are summarized in Supplementary Table S1 in IJSEM Online. No characteristic phenotype profile was found for L. lactis or L. argentinum as suggested in the literature (Dicks et al., 1993), although the differentiation proposed by the latter authors was only valid for a minority of the strains tested. Most of the Romanian isolates showed atypical features compared with the type strains L. argentinum LMG $18543^{\mathrm{T}}$ and L. lactis LMG $8894^{\mathrm{T}}$ and most had fermentation patterns more similar to L. lactis LMG 7940. The inability of the strains to ferment D-galactose, except for L. lactis LMG $8894^{\mathrm{T}}$, is in disagreement with previous reports. In addition, strain $L$. lactis $\mathrm{LMG} 8894^{\mathrm{T}}$ did not ferment fructose, an activity regarded as positive for all L. lactis strains (Garvie, 1986). Leuconostoc sp. LMG 22660 was the only strain that hydrolysed aesculin. The same strain also exhibited an atypical fermentation pattern for some other carbohydrates (see Supplementary Table S1 in IJSEM 
Online). Leuconostoc sp. LMG 22650 and LMG 22660 were unique in their ability to ferment D-xylose. These observations indicate considerable variability in the physiological characterization of strains belonging to the L. lactis group and identification is only reliable after confirmation with molecular techniques. The inability to differentiate L. lactis from $L$. argentinum using phenotypic features was noted in the original description of L. argentinum by Dicks et al. (1993).

The data from the present study show that the type strain of $L$. argentinum and all the Romanian dairy isolates are members of the species L. lactis. Consequently, it is proposed that $L$. argentinum Dicks et al. 1993 be considered as a later synonym of L. lactis Garvie 1960.

\section{Acknowledgements}

This research was supported by the Prime Minister's Services - Federal Office for Scientific, Technical and Cultural Affairs, Belgium. The authors further acknowledge financial support from the International Scientific and Technological Cooperation between Flanders and Romania of the Administration of Science and Innovation in Flanders (AWI-BIL01/52) and the Ministry of Education, Research and Youth in Romania.

\section{References}

de Man, J. C., Rogosa, M. \& Sharpe, M. E. (1960). A medium for the cultivation of lactobacilli. J Appl Bacteriol 23, 130-135.

Dicks, L. M. T., Fantuzzi, L., Gonzalez, F. C., Du Toit, M. \& Dellaglio, F. (1993). Leuconostoc argentinum sp. nov., isolated from Argentine raw milk. Int J Syst Bacteriol 43, 347-351.

Ezaki, T., Hashimoto, Y. \& Yabuuchi, E. (1989). Fluorometric deoxyribonucleic acid-deoxyribonucleic acid hybridization in microdilution wells as an alternative to membrane filter hybridization in which radioisotopes are used to determine genetic relatedness among bacterial strains. Int J Syst Bacteriol 39, 224-229.

Farrow, J. A. E., Facklam, R. R. \& Collins, M. D. (1989). Nucleic acid homologies of some vancomycin-resistant leuconostocs and description of Leuconostoc citreum sp. nov. and Leuconostoc pseudomesenteroides sp. nov. Int J Syst Bacteriol 39, 279-283.

Gancheva, A., Pot, B., Vanhonacker, K., Hoste, B. \& Kersters, K. (1999). A polyphasic approach towards the identification of strains belonging to Lactobacillus acidophilus and related species. Syst Appl Microbiol 22, 573-585.

Garvie, E. I. (1960). The genus Leuconostoc and its nomenclature. J Dairy Res 27, 283-292.

Garvie, E. I. (1986). Genus Leuconostoc. In Bergey's Manual of Systematic Bacteriology, vol. 2, pp. 1071-1075. Edited by P. H. A. Sneath, N. S. Mair, M. E. Sharpe \& J. G. Holt. Baltimore: Williams \& Wilkins.

Gevers, D., Huys, G. \& Swings, J. (2001). Applicability of rep-PCR fingerprinting for identification of Lactobacillus species. FEMS Microbiol Lett 205, 31-36.

Goris, J., Suzuki, K., De Vos, P., Nakase, T. \& Kersters, K. (1998). Evaluation of a microplate DNA-DNA hybridization method compared with the initial renaturation method. Can J Microbiol 44, 1148-1153.

Marmur, J. (1961). A procedure for the isolation of deoxyribonucleic acid from microorganisms. J Mol Biol 3, 208-218.

Mesbah, M., Premachandran, U. \& Whitman, W. B. (1989). Precise measurement of the $\mathrm{G}+\mathrm{C}$ content of deoxyribonucleic acid by highperformance liquid chromatography. Int J Syst Bacteriol 39, 159-167.

Pot, B., Vandamme, P. \& Kersters, K. (1994). Analysis of electrophoretic whole-organism protein fingerprints. In Chemical Methods in Prokaryotic Systematics, pp. 493-521. Edited by M. Goodfellow \& A. G. O'Donnell. Chichester: Wiley.

Thompson, F. L., Hoste, B., Vandemeulebroecke, K. \& Swings, J. (2001). Genomic diversity amongst Vibrio isolates from different sources determined by fluorescent amplified fragment length polymorphism. Syst Appl Microbiol 24, 520-538.

Torriani, S., Clementi, F., Vancanneyt, M., Hoste, B., Dellaglio, F. \& Kersters, K. (2001). Differentiation of Lactobacillus plantarum, $L$. pentosus and L. paraplantarum species by RAPD-PCR and AFLP. Syst Appl Microbiol 24, 554-560.

Vancanneyt, M., Mengaud, J., Cleenwerck, I., Hoste, B. \& 7 other authors (2004). Reclassification of Lactobacillus kefirgranum Takizawa et al. 1994 as Lactobacillus kefiranofaciens subsp. kefirgranum subsp. nov. and emended description of L. kefiranofaciens Fujisawa et al. 1988. Int J Syst Evol Microbiol 54, 551-556. 